\title{
Efforts to preserve the sustainability of subak irrigation system in Denpasar city, Bali Province, Indonesia
}

\author{
I Nyoman Norken ${ }^{1, *}$ \\ ${ }^{1}$ Department of Civil Engineering, Universitas Udayana, Badung, Bali, Indonesia
}

\begin{abstract}
Subak as an irrigation system in Bali is estimated to have existed before the IX century and up to now subak has consistently maintained the continuity of traditional irrigation management and operation of the irrigation system. Subak is a socio-agrarian and religious based on the philosophy of Tri Hita Karana rooted in Hindu philosophy. The challenge of subak in general is that the shrinking of the subak area, the farmers are unable to achieve a decent living, the age of the farmers is over 40 years, the financial burden that farmers bear in doing subak activities is very heavy. The condition is also very much felt in the city of Denpasar as the capital of the province of Bali. The Government has determined to preserve subak as a cultural heritage to realize Denpasar as a Heritage City. The conservation effort is carried out through: maintaining the subak area through local regulations as green open space (RTHK), providing various assistance such as: exempting subak areas from taxes and providing insurance assistance in case of crop failure, assistance for ritual implementation, irrigation channel repair assistance, production facilities, agricultural equipment assistance, incentives for subak managers, providing assistance in realizing subak as ecotourism, plan to provide scholarships for the children of subak farmers.
\end{abstract}

\section{Introduction}

The traditional irrigation system in Bali is known by the name of subak and has been passed down from generation to generation in a very long time. Subak in Bali is predicted to have existed before the IX century, and up to now, the subak system has consistently maintained the sustainability of traditional irrigation management and operation. Subak is a socio-agrarian-religious based on the philosophy of Tri Hita Karana rooted in Hindu philosophy, namely the creation of harmony between man and God (called Parahyangan), humans and other humans (called Pawongan) and humans and the environment (called Palemahan). The beauty of the wide and terraced subak landscape and the implementation of Tri Hita Karana philosophy in carrying out the agriculture and water management tradition of irrigation were recognized as World Cultural Heritage by UNESCO in 2012 [1].

Although subak is very famous in the world related to the beauty of nature and the excellent management irrigation system, many observers and researchers are anxious about

* Corresponding author: inorken@yahoo.co.uk 
the existence and sustainability of subak in Bali. Finlayson and Paramita [2] state that the subak areas have been reduced considerably from year to year due to the transfer of their function. If no steps are taken, it is feared that the subak will be destroyed. While Sukita [3] quoting Professor, I Wayan Windia from Udayana University's Subak Studies Center states that high sales of rice fields cause the destruction of the subak system and the agricultural system which are the foundation and integral part of Balinese culture. If the subak system is destroyed, then it is feared Balinese cultural heritage will also not be preserved. Furthermore, Norken et al. [4] maintain that in addition to the shrinking of subak land areas, the challenge in subak is also related to various aspects, such as: farmers are unable to achieve a decent life due to small amount of land ownership, decreasing quantity of water resources and pollution, the age of subak members on average is over 40 years, the financial burden of the farmers is weighty in carrying out subak activities, unclear regulations at the national level in regulating irrigation including traditional irrigations.

The problem of subak in Denpasar City as the capital of Bali Province is not much different from subak problems in general, even much more intense, because as the capital city, urbanization level is very high and is the main trigger of the change of function of the rice field (subak) for allotment of housing, commercial, tourism, and so forth. Nevertheless, the Denpasar City Government has determined to preserve it as a cultural heritage even though it is not part of the world cultural heritage area. This paper attempts to comprehensively describe the efforts of the Denpasar Government together with various agencies to preserve subak as an ancestral heritage and has been recognized as a world cultural heritage.

\section{Methodology}

This research was conducted for two months starting from March 2018 until April 2018, by doing in-depth interviews with the Head (Pekaseh) of Subak Anggabaya, Pekaseh of Subak Umalayu and Pekaseh of Subak Umadesa in East Denpasar Subdistrict and Pekaseh of Subak Sembung in North Denpasar Subdistrict made a model in preserving the subak that still exists in the City of Denpasar as the capital of Bali Province, Indonesia. The research was also conducted by direct observation of various activities to preserve the subak that is still operating in the middle of Denpasar City. Besides in-depth interviews and direct observation, this study is also supported by a review of various literature relating to subak in general in Bali Province.

\section{Results and discussion}

\subsection{Existence and development of subak}

According to Norken et al. [5] the subak system is believed to have started since the presence of rice fields in Bali in the 9th century in the inscription of Sukawana AI, 882 AD, which mentions the word "huma" meaning rice field, while on Bebetin AI inscription 986 AD mentions "undagi pangarung" which means the builder of water tunnel, then in Pandak Badung inscription of $1071 \mathrm{AD}$ and Klungkung of $1072 \mathrm{AD}$, there was a writing "kasuwakan" or "kasubakan" which means irrigation area. In Denpasar City, however, until now, there have been no records that can be referenced about the beginning of the existence of the subak system in the city of Denpasar. But looking at the history of the presence of Denpasar which used to become part and capital of Badung Regency that has a long history including the existence of subak system and seen from the water source for the current subak system, it is entirely a water source of a retrieval construction that has been built long 
ago and repaired by the Dutch Colonial Government, such as: Mambal weir fixed with river stone masonry in 1924 to irrigate some subaks in North Denpasar Sub-Districts and West Denpasar Sub-Districts, Peraupan weirs for the source of some subak in North Denpasar Sub-district was repaired with river stone masonry in 1926, Kedewatan weir was repaired with river stone masonry in 1926 which became a source of water in East Denpasar SubDistrict, Oongan weir was repaired with river stone masonry in 1925 to irrigate some subaks in East Denpasar and South Denpasar Sub-Districts [6, 7]. Similarly, the water source for other subaks in Denpasar City is estimated to have existed since a long time ago, along with the existence of other subaks living on the island of Bali.

Although subak has existed since long time ago, but formally the definition of subak is set forth in the Regional Regulation (Perda) of Bali Province No. 02/PD/DPRD/1972 on Regional Irrigation of Bali [8], while in the Regional Regulation of Bali Province, No. 9 of 2012, About Subak, as a substitute for Regulation No. 02/PD/DPRD/1972, the definition of subak is: "traditional organization in the field of water use and/ or plant management at the farming level of the indigenous people in Bali which is socio-agrarian, religious, and economic in nature and historically it keeps developing" [9]. Also, some researchers give subak definitions according to their respective views, such as [5], and in principle, subak is a traditional irrigation system governed by the philosophy of Tri Hita Karana.

The decline in rice fields is a significant challenge to preserve subak in the future because recently there has been a conversion of rice fields into non-rice field areas totaling 1,000 hectares per year and potentially the conversion will continue [2]. Similarly, the amount of rice fields in Denpasar City records a rapid decline in areas, along with the pace of development in various sectors, such as commercial, office, settlement, industry and other infrastructure development. Subak areas in the city of Denpasar in 1993 totaled 5753.43 hectares (ha), but they decreased to 2717 ha in 2006, and the number could still be maintained until 2014, with details consisting of 935 ha South Denpasar, East Denpasar 726 ha, West Denpasar 284 ha and North Denpasar 772 ha [7,10]. However, by 2018 there is 2,444 ha remaining; it is estimated that the shrinkage of the subak area in Denpasar reaches 20 to 30 ha per year [11]. The depletion of existing subak areas is due to the fact that land conversion is very worrying, but the number of subak in Denpasar City in 2006 was 41 subaks, if there is no effort made against this situation, it is estimated that in the future there will be no more subaks in Denpasar [7].

Regarding to subak management, Norken et al. [12] state that since Bali Island was under Majapahit Kingdom in 1343 AD, the subak management system has developed, then there was an installation of an Asedahan (later becomes Sedahan) in charge of organizing some subaks called Pasedahan, which won the trust to take care a tribute levy called suwinih or tigasana or tax for rice fields. During the Dutch colonial administration the position of sedahan was strengthened by Sedahan at the district level (Kecamatan) and Sedahan Agung at regency level (kabupaten). After independence in 1945, Sedahan/Sedahan Yeh/Pengelurah is a District Government Official that regulates and supervises irrigation water for the Subaks in its territory, while Sedahan Agung is the Government Officer of the Regency that governs and oversees the orderly irrigation within the regency. However, since the launching of the Regional Autonomy Government at the District Level in the 2000s it has had an enormous impact on the existence of Sedahan and Sedahan Agung and led to the obscurity as a government apparatus in charge of subak development. Currently, only the Regency of Tabanan is still functioning Sedahan and Sedahan Agung [5]. 


\subsection{Existence and development of subak}

\subsubsection{Irrigation network}

Subak irrigation network consists of: empelan (dam), bungas (construction for water retrieval), telabah (channel) and aungan (tunnel), tembuku (building for water division), complementary construction such as abangan (gutters), pekiyuh or pepiyuh (side overflow), petaku (construction for falling water), jengkuwung (sewer), keluwung (underground watercourse), titi (bridge) and telepus (siphon) [13], subak network in schematic form is shown in Fig 1.

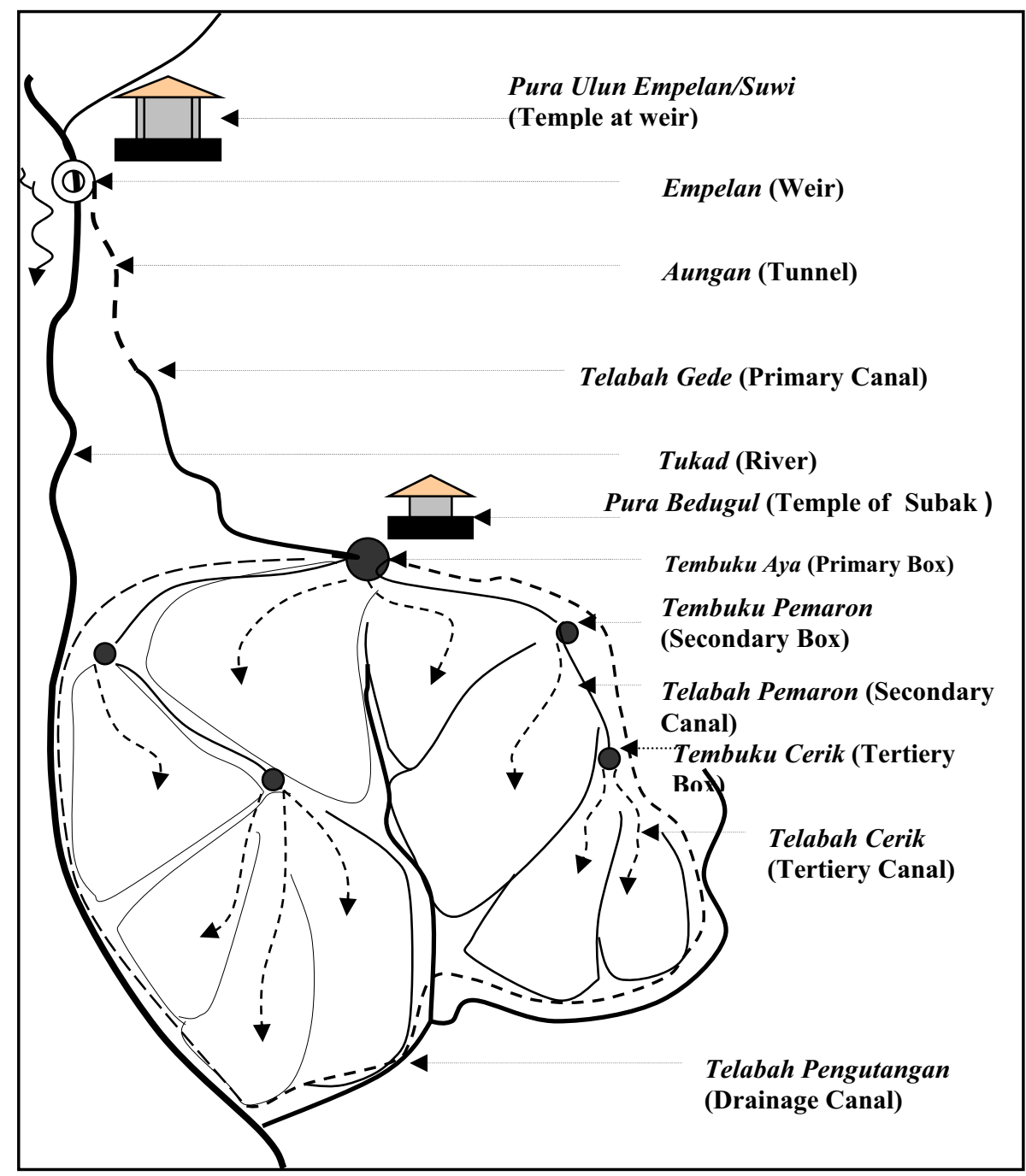

Fig. 1. Subak irrigation scheme [14].

\subsubsection{Water distribution}

Water sources in subak generally come from stream or spring water; then they flow through all water distribution, then to the canal (telabah) or tunnel (aungan). The water entering the 
channel or tunnel depends on the water level of the river flowing in the stream or the size of the spring, the higher the water source during the rainy season, the higher the water entering the channel, this is because of the free intake. For the distribution of water in the construction for water division/distribution (tembuku), the subak system uses the ratio of the area of irrigated rice fields, with the unit used to be called ayahan, which is the unit based on the amount of seed use (wit). Unit of ayahan means one unit of labor (person) that must be issued when the subak farmers hold activities, such as repairing the temple, building for or other activities. Ayahan is equivalent to one seed size (wit tenah), which is approximately equal to the area of rice fields requiring seeds of approximately $25 \mathrm{~kg}$ (or equivalent to an area of 0.3-0.5 ha). One ayahan is entitled to water of one tektek or one kecoran. Tektek or kecoran is water that flows through a cross section of a width of approximately four-finger long or $8-10 \mathrm{~cm}$ and with a depth of about $1 \mathrm{~cm}$ (Fig. 2). One tektek is different from subak to subak. Sometimes a single tektek uses long ranges of thumb tip with fingertips (called kilan) [14].

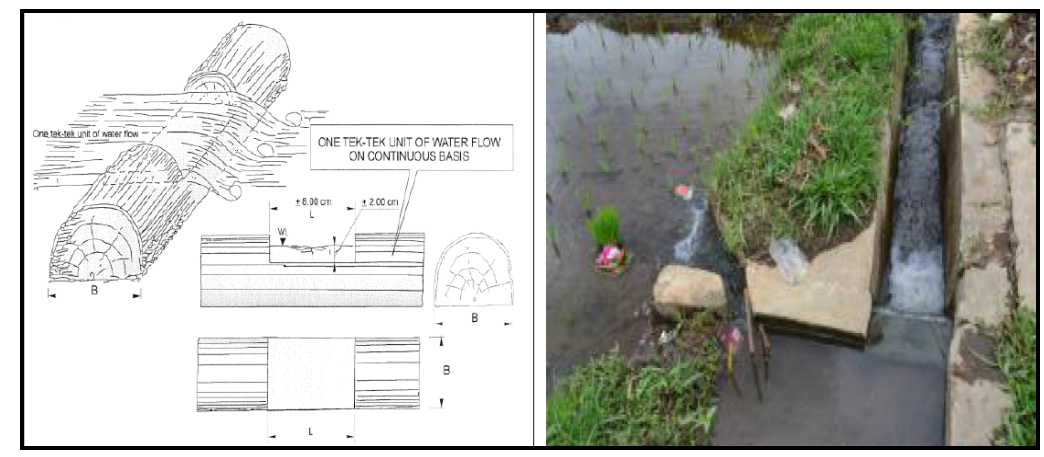

Fig. 2. Tektek system $[14,16]$.

In the subak system, the emphasis is justice in obtaining water. Therefore, this tetek unit is still coupled with the agreement of the farmers of subak members through deliberation, taking into consideration the proximity of the irrigated rice field. If the water that flows is not sufficient to irrigate the entire rice field area in one subak, then the water supply is done through rotations, i.e., subak is divided into smaller parts called tempek (subak is divided into 2 or 3 sections) subsequently water rotation is made on each tempek. Rotation patterns are usually supervised by patelik or pangliman (officer appointed to oversee the rotation of water). In addition to the rotation, the subak system also has regulation of water delivery with a nyorog system or also called nugel bungbung, i.e., arranging planting time in a nonsimultaneous way. Large subak or some subaks whose water source comes from one weir (empelan) is divided into three blocks (upstream, middle and downstream). Subak located at the upstream gets water first (called ngulu), subak situated in the middle get water after the upstream is finished cultivating the soil (called maongin), then the most downstream subak obtains water after the middle subak is completed cultivating the soil (called ngasep). Differences of water supply in each section range from 2 to 4 weeks. If the subak only utilizes waste water from the subaks in the upstream, then this subak is called subak natak tiyis. The water that has been used by the subak is then channeled through the drainage canal (telabah pengutangan). Subak disposal channel by downstream subak is used as a carrier channel (telabah), then construction for water distribution (tembuku) is built, so that water flows to the subak natak tiyis [13].

Planting pattern arrangement generally depends on the availability of water that depends on the season, during the rainy season simultaneous rice cultivation is made (kerta masa); however, in the dry season when the water is reduced the planting schedule needs to be set up with a rotating system (gadon). The subak organization regulates the timetable and 
planting pattern in details, through the time limit beginning with seeding rice seed (ngurit), up to the good time for planting rice (nandur) which includes the type of rice that can be planted, the long-lived rice/Balinese rice (tebak or tebek taun) or short-lived rice (tebak or tebek cicih). The arrangement of this cropping pattern is poured in awig-awig or by agreement (perarem) after it is done through a meeting of members (paruman), if this is violated then the farmer will be subject to sanctions in the form of fine in accordance with what has been arranged in awig-awig or perarem [13].

\subsubsection{Organization and regulation}

Each subak in Bali generally has its name, organization, and organizational structure. Subak members are called Krama Subak, and the management is called the subak prajuru. For a small subak, it is only headed by a chairman called Kelihan Subak or Pekaseh. As for the larger subak, the prajuru consists of Pekaseh (chairman), Petajuh (vice chairman), Penyarikan or Juru Tulis (Secretary), Patengen or Juru Raksa (Treasurer), Kasinoman or Juru Arah (Distributor of Information) and Saya (special assistant related to religious activities). For a very large subak or several subak called Subak Gede, and led by Pekaseh Gede and Deputy Pekaseh Gede. In the 1980s a subak organization was formed which includes one river basin called Subak Agung and led by Pekaseh Subak Agung. Subak can also be subdivided again into smaller parts called tempek/munduk and led by Kelihan Tempek/Munduk, Kelihan Tempek/Munduk is under Pekaseh [16]. Subak organizational structure can be seen in Fig. 3.

\subsubsection{Rituals in subak}

The series of rituals/religious ceremonies in subak is a religious ceremony based on Hinduism in Bali whose purpose is to ask God the Almighty manifested as Lord Vishnu (Preserver of Life in the form of water) and Dewi Sri, the manifestation of God Almighty as the Goddess of Fertility, to be given bounties and abundant crops, and to express gratitude during the planting season. The series of rituals are a manifestation of the implementation of the Parahyangan aspect of Tri Hita Karana [16] and include:

A joint ceremony, which includes: Mapag/mendak toya is a ceremony carried out when beginning to channel water from the irrigation water supply. Magurupiduka is a ceremony that is only done if there are people dies in the fields or irrigation channels. Pangwiwit is a joint ceremony when starting to plant rice. Mebalik sumpah is a ceremony performed in the event of or there is a major violation. Merebu/mecaru is a ceremony to cleanse or purify nature and human physically (sekala) and spiritually (niskala). Marekang toya or nabdab toya is a water-sharing ceremony following the agreement. Ngerestiti is a ceremony performed when the rice is one month and two months old. Ngusaba is a ceremony before the harvest of rice; the ceremony of ngusaba can be big or small depending on the planting period. Nangluk Merana is a ritual to repel pests. Pakelem is a ceremony performed jointly with all pekaseh in Pura Ulun Danu.

Individual ceremonies include: Ngendagin is a ceremony when the water first flows from the irrigation canal to the rice fields. Ngerasakin is a ceremony when finished plowing rice fields before sowing rice seedlings (ngurit). Mewinih is a ceremony when making a plot of seeding or spreading rice seeds. Ngurit is a ceremony when planting or spreading rice seeds. Nuansen is an individual ceremony (by the owner of the rice field) when starting planting rice on a good day (dewasa). Ngeroras is a ceremony performed after 12 day-old rice. Mebalik sumpah is the ceremony performed after the rice is two weeks old. Mubuhin is a ceremony held the rice is at the age of 15 days. Ngulapin is a ceremony performed after cleaning the plant pests that can adversely affect rice. 


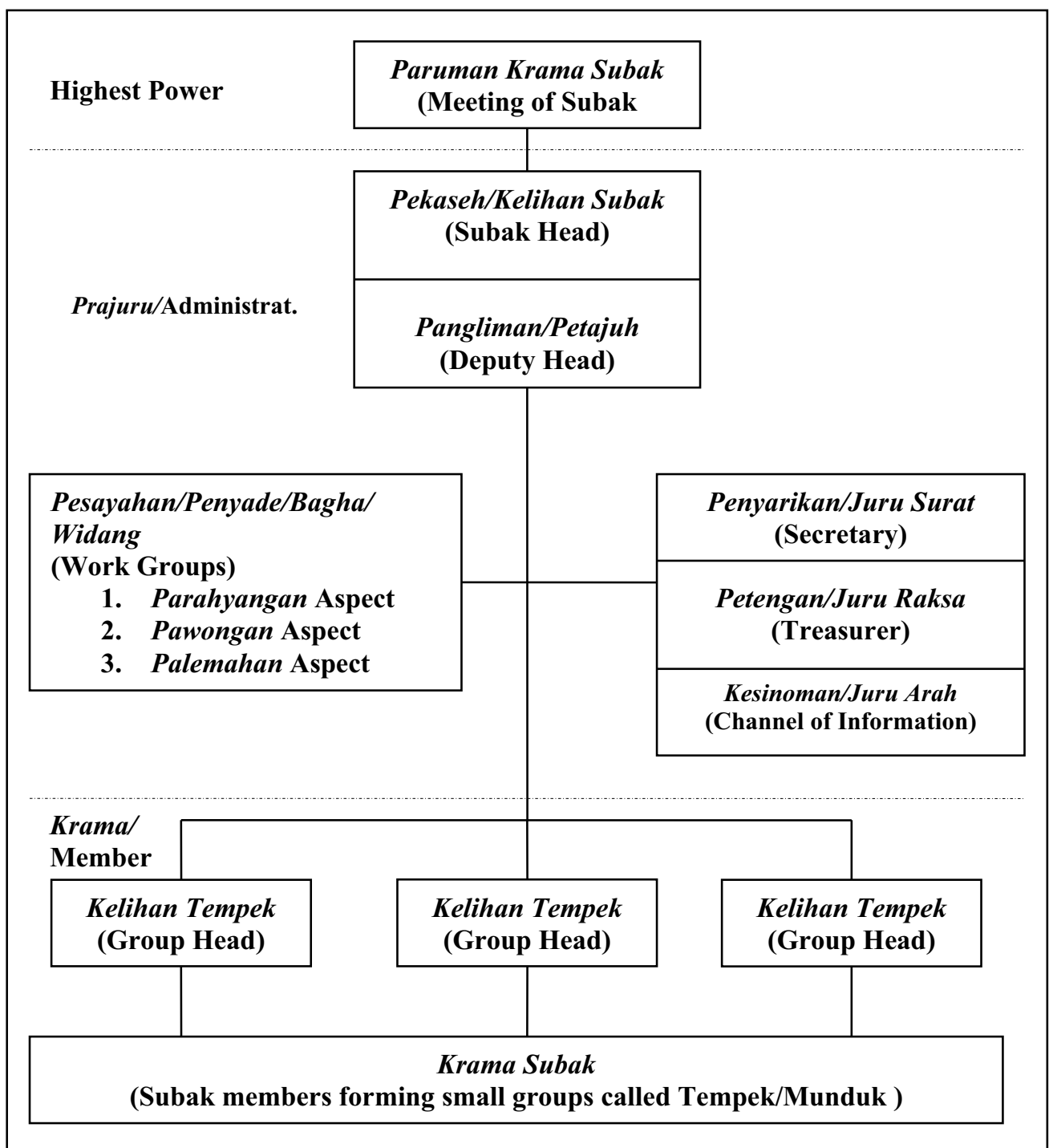

Fig. 3. Subak organizational structure [5].

Neduh is a ceremony conducted when the rice is one-month old (35 days). Ngekambuhin is the ceremony to ask for the safety of newly grown rice attended the rice is 38 days old. Mamungkah is the ceremony to beg for the protection of rice plants so that they can grow well. Nyiwa sraya is a ceremony held at the time when the rice begins to bloom. Ngiseh/biukukung is a ceremony performed when rice starts to bear fruit. Nyaeb/mecaru is a ceremony done so that rice is not attacked by pest or disease. Nyungsung is a ceremony to repel pests or disease of rice (similar to nangluk merana). Mebanten manyi/nuduk dewa/merebu is a ceremony conducted before/by the time of harvesting period by making Nini (a small bunch of rice grain that is purified and symbolizes Dewi Sri/Dewi Padi (God's manifestation as the Goddess of Fertility) to be stored in the barn. Mantenin is a ceremony conducted after the rice is stored in the barn. Rsi Gana is a ceremony held in case of disaster or various problems in one's rice field. 
For the implementation of a series of rituals in subak, each subak has some temples, and each member of subak has a ulun carik temple or sanggah catu or sanggah pengalapan, which is located in the upper reaches of the rice fields and near the water intake from the irrigation canal. For the purpose of performing rituals together by Subak members there is Pura Subak/Subak's Temple (Pura Bedugul) in each subak area, Ulun Empelan Temple near the water intake or water source construction, Pura Ulunsuwi or Pura Masceti for big subak (subak gede) or some subaks whose water is from the same source. In addition, there are temples associated with the subak such as: Ulun Danu Batur Temple, Ulun Danu Beratan Temple, Ulun Danu Tamblingan Temple, Pekendungan Temple, Tanah Lot Temple and so on which are temples for performing Pekelem or Ngerestiti ceremony, to ask Lord Vishnu, the manifestation of God the Almighty as the world preserver whose physical form is water sourced from the lake, so that the existing lake is considered a sacred place that must be preserved because it is the source of life [16, 17]. The series of rituals are still carried on by members and prajuru of subak although the series, the type, and magnitude of rituals are very different from one subak to another $[13,18]$.

\subsection{Preservation of Subak in Denpasar City}

Given the high transfer function of rice fields, it is feared in the next few years subak in Denpasar will not exist anymore. Although the subak in Denpasar is not part of the world cultural heritage, but the city government strives and is committed to preserving the subak as a cultural heritage of Balinese community that has existed since a long time ago, and is part in realizing the city of Denpasar as the Kota Pusaka (Heritage City) [12]. Various efforts that have been made include:

\subsubsection{Maintaining the subak area}

To maintain the subak areas, Denpasar City Government has included subak areas as City Green Open Space (RTHK) into Denpasar City Regulation (Perda) No. 27 of 2011 on Spatial Planning (RTRW), with total area of 1563.52 ha and consist of: 781.76 ha as Public RTHK and the area of ecotourism and the remaining 781.76 ha as Private RTHK which is a pure rice field area [19] (Fig. 4).

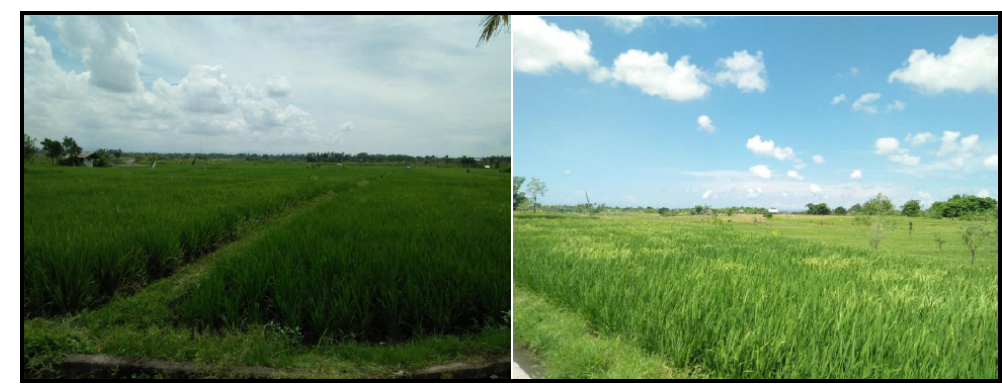

Fig. 4. Area of subak in Denpasar City.

With the inclusion of paddy fields into RTHK in the Government Regulation, it means that the conversion of rice fields into other land uses is so small that the existence of rice fields can be maintained. Since 2016 Denpasar city government has launched a sustainable subak, includes Subak Sembung, Subak Umadesa, Subak Anggabaya, Subak Umalayu, Subak Intaran Barat, and Subak Intaran Timur. The formation of sustainable subak is the government's effort in maintaining the sustainability of subak in the future. In addition to the government's efforts, the Subak Board (Prajuru) is also very supportive through changes 
in subak regulations (awig-awig) by adding the prohibition of the transfer of rice fields into other designations to the regulation if the paddy field owner sells his rice field to other parties.

\subsubsection{Maintaining Tri Hita Karana}

As a traditional irrigation system in Bali, the implementation of Tri Hita Karana is a characteristic always performed by Prajuru and krama subak wherever located, including subaks in Denpasar City. Various activities in subaks including the implementation of Tri Hita Karana aspects are set out in the form of internal rules of subak (awig-awig), perarem (additional rules) and paswara (meeting decision). The implementation includes:

\subsubsection{Aspects of Parahyangan}

Implementation of Parahyangan aspect in the city of Denpasar is not much different from the implementation in other subaks in Bali. Each subak has some temple (Pura Bedugul, Pura Ulun Empelan, etc.), Sanggah Catu/Ulun Carik (individual temple which is located in farmer's paddy field) and other temples related to subak (Fig. 5).

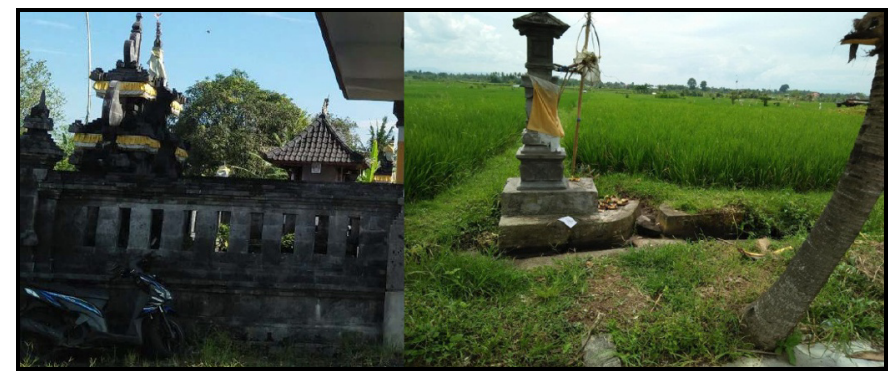

Fig. 5. Temple (Pura) of subak or Pura Bedugul and Sanggah Catu.

Krama subak also carries out rituals, both collectively and individually. Joint rituals include mapag toya, pengewiwit, ngodalin, nangluk merana, and so on. While for personal rituals, include ngendagin, mecaru, biukukung, mantenin and so on which is held in sanggah catu. In carrying out a joint ritual, especially ngodalin in Pura Bedugul, the government assists in the form of cash to each subak of Rp. 50,000,000 (Fifty Million Rupiah).

\subsubsection{Pawongan aspect}

Pawongan aspect is an effort to maintain harmony between human and other human relations. Subak in the city of Denpasar also has a board (Prajuru) led by Pekaseh. The board is equipped with the Deputy (Petajuh) who is also the supervisor of the division of water in the subak region (called pangliman), secretary (penyarikan or juru tulis or juru surat), treasurer (petengen or juru raksa) and special assistant (saya) formed to help perform religious rituals. In carrying out activities, especially when the preparation starts for the rice planting season, member meeting (paruman krama) is conducted to decide a good day to start the initial activity, i.e., to make water flow from the river to the irrigation channel by holding a ceremony mapag toya at the temple near the weir.

The meeting is held in subak hall which is built in the middle of the subak area (Fig. 6). At the meeting, members are also planning various activities during the rice planting period, such as: repairing irrigation channels, starting to cultivate the soil, beginning to plant seeds, start planting rice seeds, providing production facilities (fertilizer, seeds, 
pesticides) and so on, including rituals during rice growing season (parahyangan aspect). Prajuru also has the duty to consult with other parties, especially the government, in the case of, the assistance of agricultural innovation, especially in determining the rice varieties to be planted, the provision of seeds and fertilizers through institutions formed by subak namely: Production Facilities Service Unit (UPS) or Gapoktan (Joint Farmer Groups). In the case of coordination with other parties, since 2015 Sabha Upadesa has been formed whose responsibility is to resolve issues related to customary villages, subak and village offices [20]. Subaks in Denpasar is also incorporated in Subak Gede which is subaks having the same water source or water source come from one weir or building/construction for primary distribution which in subak system called tembuku aya. The role of prajuru is crucial in maintaining the sustainability of subak in Denpasar City, especially related to maintaining the relationship of prajuru with krama subak and the involvement of all subaks with the outsiders, especially the government that serves as a subak supervisor.

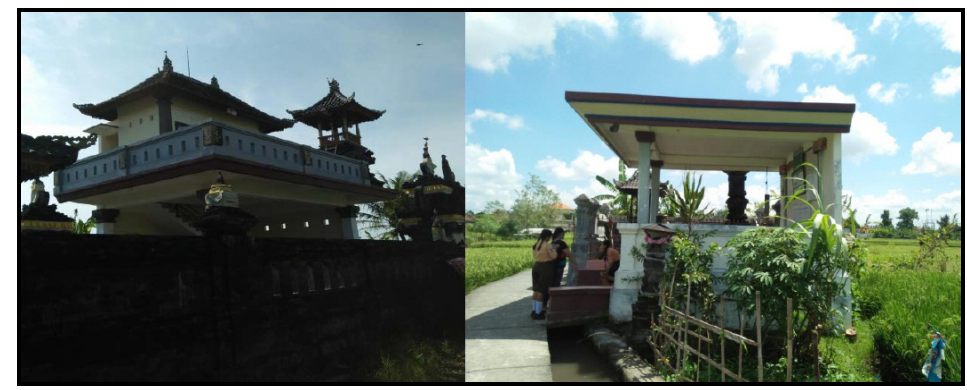

Fig. 6. Subak's hall.

\subsubsection{Palemahan aspect}

Palemahan aspect is an effort in maintaining a harmonious relationship between humans and the environment. The palemahan aspect concerns various matters relating to physical conditions in subak, such as subak areas including the ownership area of each subak member, operation and maintenance of irrigation channels and other infrastructure, water distribution and management for irrigation, planting arrangements and good farming practices. Subak should be maintained as far as possible in terms of its areas and preservation, including the ownership and prevention of rice field conversion into another land uses, as well as maintenance of irrigation channels, are kept in good condition through mutual assistance/working together, especially the quarterly channel (called cacing canals) which becomes the obligation of subak in terms of its maintenance. While the tertiary, secondary and primary channels, their repairs are carried out by the Denpasar City Government, the Provincial Government of Bali and the Central Government respectly following their respective authorities. One year cropping pattern is made twice rice and one time crops other than rice (called palawija). Rice planting period is known as kerta masa period (period of rice planting together during the rainy season) and gadon (rice planting during the dry season that some are allowed not to plant rice due to water limitations). At the time of palawija, the main commodities planted are soybeans, other than that also the farmers of subak members can plant flowers, peanuts, corn, and others following the wishes of farmers. In the case of water distribution, the tektek system is used under the existing tradition in subak (Fig. 7). When the growing season falls in the dry season (gadon), the irrigation water supply is arranged in turns and supervised by the pangliman for justice in obtaining water.

Meanwhile, water management between subak is organized by Pekaseh Gede with nyorog system where all subaks existing in Subak Gede region is divided into 3 groups 
(upstream, middle and downstream), then subak group in upstream obtain water first (ngulu), then the middle (maongin) and the last downstream (ngasep). The timing of the water distribution is done according to the difference in the time of processing of the land and can be in the range of 2 (two) weeks. Until now there has been no conflict in the distribution of water, but if a conflict occurs, then the settlement is done to reach an agreement. Subaks that belong to sustainable subak scheme in Denpasar city have been partially equipped with a pedestrian as part of ecotourism facility in subak, and other facilities for the beauty of nature in subak can be enjoyed by tourists both domestic and foreign tourists (Fig. 7).

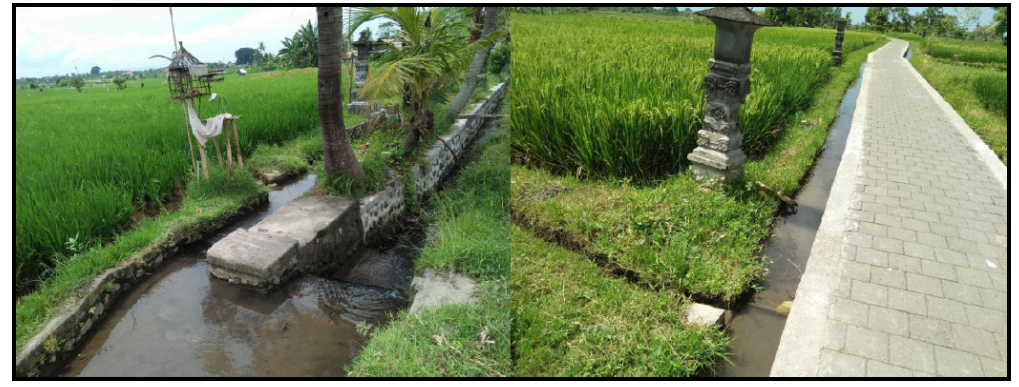

Fig. 7. Tektek system and pedestrian facility on subak.

\subsubsection{Various government assistances in subak preservation}

Denpasar City Government since the last decade has been very persistent in preserving subak by providing various assistance and support. These efforts include:

1) Tax incentives and insurance. The government offers incentives in the form of exempting the payment of existing rice taxes, so farmers can be exempted from the obligation to pay taxes. Also, farmers are also assisted in the form of insurance when it there is a crop failure, so farmers do not hesitate to keep doing rice cultivation, because if there is a failure, the farmers will not completely suffer losses.

2) Incentives for prajuru. The subak management (prajuru) who are grouped in the sustainable subak scheme are given monthly incentives of Rp. 1,500,000 (one million five hundred thousand rupiahs or about 100 USD) for pekaseh and Rp. 650,000 (six hundred fifty thousand rupiahs or approximately 40 USD) for petajuh/pangliman. The incentives began to be given in 2018 so that the prajuru can work diligently in managing the various needs and problems faced by subaks.

3) Aids of equipment and production facilities. Providing farming equipment (tractors) and subsidies for the procurement of fertilizers, seeds, and pesticides required by subaks, channeled through the Joint Farmers Group (Gapoktan) or Service Facilities Unit (UPS) established by Prajuru and Krama Subak.

4) Assistance and supervision in maintaining customs/traditions and farming. The government through the Cultural Department of Denpasar City gives assistance to changes in internal rules (awig-awig) of subaks and provides money relief related to the implementation of rituals conducted by subaks and provide a variety of assistance related to the technical application of farming from the Department of Agriculture.

5) Distribution of rice crops. Denpasar City Government is currently helping farmers to distribute the harvests which are already in the form of rice to be purchased by all employees in the Denpasar City Government so that farmers of subak members can get a decent price.

6) Support and help subak area to become ecotourism area. Providing supervision so that subak areas in Denpasar can become ecotourism areas by building supporting facilities 
such as pedestrian for jogging tracks, including helping to repair and maintain irrigation channels especially tertiary channels in the middle of subak area.

7) Plan for giving a scholarship. In the future, the Government will provide a scholarship for the children of subak farmers to improve their education up to the undergraduate level.

The various assistances provided by the government have been felt by the subak members especially in increasing their income as farmers so that both Prajuru and Krama subak are very enthusiastic and committed to preserving subaks in Denpasar City.

\section{Conclusions}

From the above description it can be concluded as follows. Subak is a traditional irrigation system in Bali, built since the IX century based on the philosophy of Tri Hita Karana and since 2012 it has been recognized as World Cultural Heritage by UNESCO. Subak is a socio-agrarian-religious based on the philosophy of Tri Hita Karana, which is the creation of harmony between man and God/Creator (Parahyangan), humans and other humans (Pawongan) and humans and the environment (Palemahan), rooted in Hindu philosophy. Subak in the city of Denpasar currently amounts to 43 subaks with an area of 2,444 ha, and there is shrinkage of about 20-30 ha each year. To maintain the existing subak areas in Denpasar City, the government has included the subak area as Green City Open Space (RTHK) and putting it into Local Regulation (Perda), and establishing sustainable subaks.

As a Heritage City, the Government of Denpasar City is very committed to defending subak as a cultural heritage by providing various assistance, including: tax and insurance incentives, money incentives for subak management, equipment and facilities of farming production, and supervision in maintaining customs/traditions and carrying out the farming businesses, channeling the harvest especially rice, encouraging and developing the city to become ecotourism area, and planning to provide scholarship for children of subak farmers in Denpasar City.

On this occasion the author expresses his sincere thanks to fellow lecturers at the Civil Engineering Study Program, Faculty of Engineering, Udayana University, for providing inputs and encouragement, so that this paper can be completed in accordance with a predetermined schedule.

\section{References}

1. M. Ukirsari, Plakat UNESCO, Pengakuan Subak sebagai warisan dunia 2012. Available at: https://archive.vn/e0CPz (2012)

2. R. Finlayson, E. Paramita, Subak, sistem irigasi khas Bali, berada di ambang kehancuran. Available at: http:/www.worldagroforestry.org/news/subak-sistemirigasi-khas-bali-berada-di-ambang-kehancuran (2013)

3. I.K. Sutika. Kekhawatiran lenyapnya sistem subak di Bali. Available at: http://www.antarabali.com/berita/49575/kekhawatiran-lenyapnya-sistem-subak-di-bali (2014).

4. I.N.Norken, I.K. Suputra, I.G.N.K. Arsana, J AST 6, 215 (2016)

5. I.N.Norken, I.K. Suputra, I.G.N.K. Arsana, J AAH 21, 245 (2017)

6. I.G.M. Suadnya, Devp. and maintenance of subak irrigation networks (Upada Sastra, Denpasar, 1993) 
7. I.K. Suputra, Effectiveness of water resources management for subak irrigation water requirement in Denpasar City (Post Graduate Program of Udayana University, Denpasar, 2008)

8. I.G.N. Partha, Regional regulation (Perda) of Bali No. 02/PD/DPRD/1972 of the Bali Provincial irrigation (Upada Sastra, Denpasar, 1993)

9. M.M. Pastika Regional regulation (Perda) of Bali No. 9 year 2012 of the Subak (Provincial Legislature of Bali, Denpasar, 2012)

10. I.P. Astawa, Bali development data 2013 (Gov. of Bali Province, Denpasar, 2014)

11. Asmara, Setiap tahun sawah menyusut 20-30 hektar. Available at: http://www.balipost.com/news/2018/01/15/34540/Setiap-Tahun-Sawah-Menyusut-2030...html (2018) 11

12. I.N. Norken, Denpasar Heritage City from the perspective of irrigation and drainage (Planning Board of Denpasar Municipal, Denpasar, 2013)

13. I.N. Norken, I.K. Suputra, I.G.N.K. Arsana, Proc. of the International Commision on Irrigation and Deainage (ICID-CIID) (2010)

14. I.N. Norken, I.K. Suputra, I.G.N.K. Arsana, Appl. Mech. and Mat. 776, (2015)

15. I.N. Norken, Subak and water resources dev.t in Bali (Upada Sastra, Denpasar, 1993)

16. M.I. Yekti, B. Schultz, I.N. Norken, A.H. Gany, L. Hayde, J. Irrig. Drain 66, 4 (2017)

17. J. Sushila, Typical Characteristics of subak irrigation system in Bali (Public Works Department of Bali Province, Denpasar, 1987)

18. I.G. Pitana, Subak, traditional irrigation system in Bali: A general description (Upada Sastra, Denpasar, 1993)

19. Pemerintah Kota Denpasar, Peraturan Daerah Kota Denpasar no. 27 tahun 2011 tentang Rencana Tata Ruang Wilayah Kota Denpasar Tahun 2011-2031 (Walikota Denpasar, Denpasar, 2011)

20. J. Marbun, Pemkot Denpasar bentuk Sabha Upadesa. Available at: https://www.republika.co.id/berita/nasional/daerah/14/05/23/n6018r-pemkot-denpasarbentuk-sabha-upadesa (2014) 